\title{
Pembuktian Tindak Pidana Zina Berdasarkan Bukti Petunjuk: Analisis Putusan Pengadilan No. 506/Pid.B/2017/PN Smn
}

\author{
Dayu Putra \\ Fakultas Hukum Universitas Islam Indonesia Yogyakarta Indonesia \\ Jln. Cik Di Tiro No. 1, Yogyakarta, Indonesia 55223 \\ dayuputra@live.com
}

\begin{abstract}
Abstrak
This study discusses the use of indicative evidence as a basis for proving adultery and what kind of indicative evidence has the justification for proving adultery. The research method used is normative juridical with a case and statutory approach. The results of the study concluded that: First, the use of indicative evidence is very much dominated by the subjectivity of judges. This evidence is used after the judge is absolutely sure that the defendant has committed adultery based on the conformity and logical relationship between each fact and the element of adultery that is to be proven. When using indicative evidence, the judge strongly emphasized the fact that the defendant was together in a closed room within a period of time that allowed for adultery, to be linked to the Supreme Court Decision Number 854K / Pid / 1983, which became the legal source of proof of adultery or sexual intercourse. The use of indicative evidence is always linked to the inability of the defendant to prove his argument; and Second, indicative evidence that has justification must meet the formal and material requirements.
\end{abstract}

Key Words: Crime of adultery; indicative evidence; rule of evidence

\begin{abstract}
Abstrak
Penelitian ini membahas penggunaan bukti petunjuk sebagai dasar membuktikan unsur zina dan bukti petunjuk macam apa yang memiliki justifikasi membuktikan unsur zina. Metode penelitian yang digunakan bersifat yuridis normatif dengan pendekatan kasus dan perundang-undangan. Hasil penelitian menyimpulkan bahwa: Pertama, penggunaan bukti petunjuk sangat didominasi oleh subjektivitas hakim. Bukti ini digunakan setelah hakim yakin betul bahwa terdakwa telah melakukan zina berdasarkan persesuaian dan hubungan logis antara masing-masing fakta dengan unsur zina yang hendak dibuktikan. Ketika menggunakan bukti petunjuk, hakim sangat menekan adanya fakta kebersamaan terdakwa di kamar tertutup dalam jangka waktu yang memungkinkan terjadinya zina, untuk dihubungkan dengan Putusan Mahkamah Agung Nomor 854K/Pid/1983, yang menjadi sumber hukum pembuktian unsur zina atau persetubuhan. Penggunaan bukti petunjuk juga selalu dihubungkan dengan ketidakmampuan terdakwa membuktikan bantahannya; dan Kedua, bukti petunjuk yang memiliki justifikasi harus memenuhi syarat formil dan materil.
\end{abstract}

Kata- kata Kunci: Bukti petunjuk; pembuktian; tindak pidana zina 


\section{Pendahuluan}

Overspel yang diterjemakan ke dalam bahasa Indonesia dengan istilah "zina"1 atau "gendak" 2 atau "mukah" 3 merupakan tindak pidana yang tergolong ke dalam kejahatan kesusilaan atau melanggar kesopanan. Tindak pidana ini diatur dalam Pasal 284 Kitab Undang-Undang Hukum Pidana (KUHP) dengan unsur-unsur pokok sebagai berikut: Pertama, laki-laki atau perempuan yang telah kawin; Kedua, berbuat zina; dan Ketiga, dengan perempuan atau laki-laki yang bukan isteri atau suaminya.

Pembentuk undang-undang tidak menjelaskan apa yang dimaksud dengan zina. Menurut doktrin, zina atau gendak atau mukah ialah persetubuhan, sedangkan yang dimaksud dengan persetubuhan ialah perpaduan antara kemaluan laki-laki dan perempuan yang biasa dijalankan untuk mendapatkan anak, jadi kemaluan laki-laki harus masuk kedalam kemaluan perempuan. ${ }^{4}$

Salah satu problematika pembuktian tindak pidana zina ialah sulitnya membuktikan unsur zina atau persetubuhan, sebab perbuatan tersebut selalu dilakukan sembunyi-sembunyi dan terjadi dalam ruang-ruang private. Akibatnya sulit atau bahkan tidak mungkin memperoleh alat bukti saksi yang melihat langsung peristiwa terjadinya persetubuhan, sementara fakta hukum yang harus dibuktikan adalah masuknya alat kelamin laki-laki ke dalam lubang kemaluan perempuan. Itu sebabnya dalam praktiknya, pembuktian unsur zina dilakukan dengan menggunakan bukti petunjuk.

Alat bukti petunjuk pada hakikatnya bukanlah suatu alat bukti melainkan pemikiran atau pendapat hakim yang diperoleh dari alat bukti lain dan kemudian dijadikan sebagai alat bukti di persidangan. Singkatnya, bukti petunjuk bukan alat bukti yang sebenarnya melainkan kesimpulan hakim belaka, yang menganggap terbuktinya unsur zina karena terbuktinya peristiwa-peristiwa lain yang berhubungan erat dengan peristiwa zina yang hendak dibuktikan. Pembuktian ini dalam konteks teori pembuktian disebut sebagai pembuktian tidak langsung. Sebagai contoh, untuk membuktikan peristiwa A terlebih dahulu dibuktikan peristiwa B dan C. Apabila peristiwa B dan C terbukti maka peristiwa

\footnotetext{
299-300.

${ }^{1}$ R. Sugandhi, Kitab Undang-Undang Hukum Pidana dan Penjelasannya, Usaha Nasional, Surabaya, 1981, hlm.

${ }^{2}$ R. Soenarto Soerodibroto, KUHP DAN KUHAP Dilengkapi Yurisprudensi Mabkamah Agung dan Hoge Raad, RajaGrafindo Persada, Jakarta, 2006, hlm. 170 - 171.

${ }^{3}$ Andi Hamzah, Delik-Delik. Tertentu (Speciale Delicten) Di Dalam KUHP. Sinar Grafika, Jakarta, 2017, hlm. 169

${ }^{4}$ R. Soesilo, Kitab Undang-Undang Hukum Pidana (KUHP) serta Komentar-Komentarnya Lengkap Pasal Demi Pasal, Politea, Bogor, 1995, hlm. 209.
} 
A dianggap terbukti pula. Begitu pula dalam perkara tindak pidana zina, apabila A dan B berada dalam satu kamar tertutup maka A dan B "dianggap telah berbuat zina", sehingga dengan sendirinya unsur zina telah terpenuhi.

Mengingatnya sifat bukti petunjuk merupakan hasil pemikiran hakim maka subjektivitas hakim menjadi lebih dominan. Padahal belum tentu laki-laki dan perempuan yang berada dalam kamar tertutup telah berbuat zina atau bersetubuh. Atau bisa saja hendak bersetubuh tetapi tidak jadi, atau belum terlaksana karena terlanjur digrebek.

Dari segi hukum, keadaan bugil sekalipun belum dapat dikatakan telah berbuat zina. Keadaan bugil dalam satu kamar paling-paling dianggap pelanggaran moral atau dituduh selingkuh atau berbuat serong, tapi belum dapat dikatakan berbuat zina. Karena masih bisa dipertanyakan apakah perbuatan selingkuh atau serong yang mereka lakukan sudah benar-benar sampai ketingkat berhubungan kelamin secara fisik dan biologis. Oleh karena itu, penggunaan bukti petunjuk yang kuranghati-hati cenderung kepada overcriminalization dan penerapan hukum yang sewenang-wenang.

\section{Rumusan Masalah}

Berdasarkan uraian-uraian tersebut permasalahan pokok yang akan dikaji dalam penelitian ini sebagai berikut: Pertama, bagaimana hakim dalam putusannya menggunakan bukti petunjuk sebagai dasar membuktikan unsur delik zina? Kedua, bagaimana bukti petunjuk bisa memiliki justifikasi untuk membuktikan unsur delik zina?

\section{Tujuan Penelitian}

Penelitian ini bertujuan: Pertama, untuk mengetahui penggunaan bukti petunjuk oleh hakim sebagai dasar pembuktian delik zina. Kedua, untuk mengetahui bukti petunjuk yang bisa memiliki justifikasi untuk membuktikan delik zina.

\section{Metode Penelitian}

Penelitian ini menggunakan metode penelitian yuridis normatif dengan pendekatan kasus dan perundang-undangan. Bahan hukum primer yang digunakan ialah peraturan perundang-undangan dan putusan pengadilan, ${ }^{5}$ yang didukung pula dengan bahan hukum sekunder berupa buku-buku hukum, jurnal hukum, penelitian hukum, pendapat para sarjana hukum, kamus hukum dan 
sebagainya. Bahan hukum tersebut diperoleh melalui studi dokumen dan studi kepustakaan, yang kemudian dianalisis secara kualitatif.

\section{Hasil Penelitian dan Pembahasan}

\section{Penggunaan Bukti Petunjuk oleh Hakim sebagai Dasar Membuktikan Unsur Delik Zina}

Bukti petunjuk merupakan salah satu dari empat alat bukti yang sah sebagaimana diatur dalam Kitab Undang-Undang Hukum Acara Pidana (KUHAP). Keberadaan bukti petunjuk dalam KUHAP diatur dalam 2 pasal, yaitu Pasal 184 dan 188 KUHAP. Pasal 184 KUHAP menerangkan bahwa bukti petunjuk adalah alat bukti sah, sedangkan Pasal 188 mengatur tentang batasan, sumber perolehan dan penilaian kekuatan pembuktian dari bukti petunjuk.

Defenisi petunjuk berdasarkan Pasal 188 ayat (1) KUHAP adalah "suatu perbuatan, kejadian atau keadaan yang karena persesuaianya, baik antara yang satu dengan yang lain, maupun dengan tidak pidana itu sendiri, menandakan bahwa telah terjadi suatu tindak pidana dan siapa pelakunya". Selanjutnya pada ayat (2) disebutkan bahwa bukti petunjuk hanya dapat diperoleh dari keterangan saksi, surat dan keterangan terdakwa. Secara a contrario, maka pembentukan bukti petunjuk tidak boleh di luar dari ketiga alat bukti yang telah ditentukan tersebut. Lebih lanjut pada ayat (3) menegaskan bahwa "penilaian atas kekuatan pembuktian dari suatu petunjuk dalam setiap keadaan tertentu dilakukan oleh hakim dengan arif lagi bijaksana, setelah ia mengadakan pemeriksaan dengan penuh kecermatan dan kesaksamaan berdasarkan hati nuraninya".

Alat bukti petunjuk berbeda dengan 4 alat bukti lain sebagaimana diatur dalam Pasal 184 KUHAP. Alat bukti ini bukan suatu alat bukti yang mandiri6, melainkan suatu alat bukti bentukan hakim. ${ }^{7}$ Artinya, bukti petunjuk ini merupakan pemikiran ${ }^{8}$ atau pendapat hakim yang dibentuk dari alat bukti lain, yang kemudian digunakan sebagai alat bukti dalam sidang. ${ }^{9}$ Singkatnya, bukti petunjuk pada pokoknya bukan alat bukti yang sebenarnya melainkan hanya kesimpulan hakim belaka yang diperoleh dari alat-alat bukti yang sebenarnya. ${ }^{10}$ Berbeda dengan empat alat bukti lain, yang memiliki "wadah" sendiri, seperti keterangan saksi, ahli atau terdakwa, yang memiliki bentuk objektif atau wadah

${ }^{6}$ Eddy O.S. Hiariej, Teori dan Hukum Pembuktian, Erlangga, Jakarta, 2012, hlm. 110.

${ }^{7}$ Adami Chazawi, Hukum Pembuktian Tindak Pidana Korupsi, Media Nusa Creative, Malang, 2018, hlm. 67. hlm. 102

${ }^{8}$ Alfitra, Hukum Pembuktian dalam Beracara Pidana, Perdata dan Korupsi di Indonesia, Raih Asa Sukses, Jakarta,

${ }^{9}$ Adami Chazawi, Op. Cit., hlm. 68

${ }^{10}$ Ibid., hlm. 77. 
tersendiri, yaitu orang yang memberikan keterangan. Begitu juga dengan alat bukti surat yang memiliki wadah sendiri, yaitu bentuk material surat itu. Tidak demikian halnya dengan alat bukti petunjuk, bentuknya sebagai alat bukti ini "asessor" atau tergantung pada 3 alat bukti lain, yaitu keterangan saksi, surat dan keterangan terdakwa sebagai sumber kelahirannya. ${ }^{11}$ Itu sebabnya dalam konteks teori pembuktian, bukti petunjuk tergolong sebagai alat bukti tidak langsung atau circumtantial evidence, yaitu"suatu alat bukti di mana antara fakta yang terjadi dan alat bukti tersebut hanya dapat dilihat hubungannya setelah ditarik kesimpulan-kesimpulan tertentu". ${ }^{12}$ Bukti petunjuk ini bersifat pelengkap (accessories evidence), artinya bukan suatu alat bukti yang mandiri namun merupakan alat bukti sekunder yang hanya dapat diperoleh dari bukti primer, yaitu keterangan saksi, surat dan keterangan terdakwa. ${ }^{13}$

Oleh karena bukti petunjuk merupakan pemikiran atau pendapat hakim, maka subjektivitas hakim menjadi lebih dominan. Karena itu banyak ahli yang keberatan dimasukkannya bukti petunjuk sebagai salah satu alat bukti dalam hukum pembuktian perkara pidana. Bukti petunjuk dianggap bukan merupakan alat bukti, karena pada hakikatnya tidak ada. Salah satunya datang dari van Bemmelen, yang menyatakan bahwa "kesalahan utama ialah bahwa petunjukpetunjuk dipandang sebagai suatu bukti padahal hakikatnya tidak ada". ${ }^{14}$ Hal yang sama juga disampaikan P.A.F. Lamintang, yang pada pokoknya menyatakan, alat bukti petunjuk sebenarnya bukan alat bukti melainkan anggapan hakim atas suatu kenyataan yang dijadikan alat bukti, misalnya karena adanya kesamaan antara kenyataan tersebut dengan kenyataan yang dipermasalahkan" ${ }^{15}$

Kendati demikian, harus diakui bahwa dalam banyak kasus, alat bukti petunjuk memiliki peranan yang sangat signifikan dalam membuktikan kesalahan seorang terdakwa. Seperti halnya dalam perkara tindak pidana zina. Pembuktian unsur delik zina sangat bergantung kepada bukti petunjuk, sebab tidak ada satupun alat bukti lansung, seperti saksi mata yang melihat langsung peristiwa terjadinya persetubuhan. Keterangan saksi hanya menerangkan peristiwa-peristiwa lain yang berkaitan dengan peristiwa persetubuhan, sebagaimana dapat dilihat dalam Putusan Nomor 506/Pid.B/2017/PN Smn. Kasus posisi ialah sebagai berrikut:

${ }^{11}$ Yahya Harahap, Pembahasan Permasalahan dan Penerapan KUHAP: Pemeriksaan Sidang Pengadilan, Banding, Kasasi dan Peninjauan Kembali, Sinar Grafika, Jakarta, 2015, hlm. 317

${ }^{12}$ Munir Fuady, Teori Hukum Pembuktian Pidana dan Perdata, Citra Aditya Bakti, Bandung, 2020, hlm. 5.

${ }^{13}$ Eddy O.S. Hiariej, Op. Cit., hlm. 110.

${ }^{14}$ Andi Hamzah, Hukum Acara Pidana, Sinar Grafika, Jakarta, 2013, hlm. 277.

15P.A.F. Lamintang, Pembahasan KUHAP Menurut Ilmu Pengetabuan Hukum Pidana dan Yurisprudensi, Sinar Grafika, Jakarta, 2010, hlm. 430. 
Pertama, pada hari Senin, tangal 04 Januari 2016 Pukul 23.00 Wib, Bunga (samaran) menelpon A untuk menitipkan sepeda motor sambil mengatakan sedang bersama Kumbang (samaran). Menurut C (front office Hotel), pada tangal 04 Januari 2016 sekira malam hari ada orang yang memesan kamar Hotel dan menyerahkan KTP atas nama Kumbang sebagai jaminan, tapi C tidak ingat lagi wajahnya dan tidak tahu apakah sendiri atau berdua. Yang mengantar ke dalam kamar No. 26 adalah petugas hotel lain. Selanjutnya menurut keterangan A dan B (suami isteri), pada hari Selasa tanggal 5 Januari 2016 sekira pukul 04.30 Wib (subuh), Bunga datang ke rumah A dan B diantar oleh Kumbang. Bunga masuk ke dalam rumah, sedangkan Kumbang langsung pulang. Menurut A, di dalam rumah Bunga memperlihatkan kunci yang ada logo Hotel. Bunga juga mengatakan baru selesai nemani Kumbang dan Bunga dikasih duit, sambil memperlihatkan uang sekira sejuta. Bunga juga mengajak A untuk berenang pada pagi harinya karena masa check out masih panjang sampai Pukul 12.00 Wib. Setelah selesai mengantar anak sekolah, A datang lagi ke rumah A untuk mengajak berenang ke Hotel. Selesai berenang, A dan Bunga masuk kamar No. 26 untuk mandi dan ganti pakaian. Di dalam kamar, A melihat kondisi kamar berantakan, banyak tisu berserakan. A dan B juga sempat fotofoto selfi. Saat itu, Bunga juga ada cerita kepada A kalau Bunga berhubungan badang dengan Kumbang. Setelah itu, lalu Bunga menyerahkan kunci kamar ke receptionis hotel sekaligus mengambil KTP Kumbang. Menurut D (receptionist), yang mengembalikan kunci dan mengambik KTP adalah Bunga sendiri. Setelah itu, A, Bunga dan A mengantarkan KTP tersebut kepada Kumbang.

Berdasarkan keterangan A, B, C dan D, majelis hakim meyakini keberadaan Bunga dan Kumbang bersama di kamar nomor 26. Walaupun Bunga dan Kumbang menyangkal keberadaan mereka bersama di Hotel akan tetapi menurut majelis hakim, mulai dari rangkaian pemesanan hotel oleh Kumbang sampai dengan keberadaan terakhir kunci kamar hotel yang dipegang oleh Bunga telah memberikan petunjuk ke arah kebersamaan mereka di hotel tersebut. Keyakinan majelis ini diperkuat pula dengan ketidakmampuan Kumbang membuktikan sangkalannya, yang mengatakan bahwa benar ia ada memesan kamar tapi tidak pernah bersama Bunga dan kunci kamar juga tidak pernah diberikan kepada Bunga melainkan kepada kawannya bernama F. Begitu juga dengan keterangan Bunga yang menyatakan bahwa ia mendapatkan kunci dari F. Akan tetapi, karena Kumbang dan Bunga tidak pernah dapat menghadirkan F, majelis semakin yakin kebenaran Kumbang dan Bunga di kamar tersebut. Keyakinan majelis hakim dihubungkan pula dengan kejanggalan dari keterangan Kumbang yang menyebut $\mathrm{F}$ adalah teman dekatnya dan merupakan isteri dari temannya tetapi di dalam BAP Kepolisian F adalah seorang janda. Berdasarkan hal tersebut selanjutnya hakim terlebih dahulu membentuk alat bukti petunjuk untuk membuktikan fakta hukum kebersamaan Kumbang dan Bunga di kamar No. 26. 
Setelah itu majelis hakim menghubungkannya dengan Putusan Mahkamah Agung Nomor 845K/Pid/1983 yang mengandung kaidah hukum "seorang lakilaki terbukti bersama-sama dengan seorang perempuan dalam satu kamar pada suatu tempat tidur merupakan petunjuk bahwa laki-laki itu telah bersetubuh dengan perempuan tersebut". Dengan demikian, oleh karena Bunga dan Kumbang terbukti dalam satu kamar tertutup dan ada tempat tidurnya berdasarkan bukti petunjuk maka majelis hakim berpendapat telah terjadi persetubuhan yang dilakukan keduanya.

Kedua, pada hari Selasa tanggal 10 Mei 2016 sekira Pukul 23.40 Wib, Terdakwa Kumbang bersama Bunga dengan mengendarai mobil milik Bunga memesan kamar di sebuah Losmen. Setelah mendapat kamar No. 17, Kumbang dan Bunga masuk ke dalam kamar No. 17 diantarkan A (petugas Losmen), lalu Terdakwa Kumbang memesan kopi dan teh kepada A. Tidak lama kemudian A mengantarkan minuman pesanannya. Selanjutnya Pukul 05. 30 Wib (pada hari Rabu tanggal 11 Mei 2016) keduanya check out. Prosedur pencatatan tamu yang berlaku di Losmen A, hanya mencatat Plat Kendaran, Nomor Kamar, Biaya, serta Jam Masuk dan Keluar, sedangkan nama tamu tidak pernah dicatat.

Berdasarkan keterangan A yang dihubungkan dengan buku tamu losmen, majelis meyakini bahwa Kumbang dan Bunga berada dalam satu kamar, yaitu kamar nomor 17 pada jam 23.40 wib hingga sampai pagi pukul 04.00 wib. Walaupun Kumbang dan Bunga menyangkal bahwa mereka tidak pernah menginap di losmen tersebut akan tetapi karena Kumbang dan Bunga punya hak sangkal dan keduanya juga tidak pernah dapat membuktikan alibinya/penyangkalannya tersebut, majelis hakim berpendapat penyangkalan terdakwa tersebut tidak beralasan hukum dan ditolak. Oleh karena terdapat fakta hukum kebersamaan kedua terdakwa di dalam kamar dan dihubungkan dengan pembuktian adanya persetubuhan sebagaimana disebutkan dalam Putusan Mahkamah Agung Nomor 854K/Pid/1983, maka majelis hakim berpendapat telah ada persetubuhan yang dilakukan Kumbang dan Bunga.

Berdasarkan pertimbangan majelis hakim tersebut, dapat disimpulkan halhal sebagai berikut. Pertama, subjektivitas hakim sangat dominan. Pada peristiwa pertama, tidak ada fakta hukum kebersamaan keduanya di dalam kamar namun karena hakim yakin betul bahwa keduanya telah melakukan persetubuhan maka majelis hakim membentuk bukti petunjuk untuk membuktikan kebersamaan keduanya di dalam kamar. Baru kemudian membentuk petunjuk baru dengan menghubungkannya kepada putusan Mahkamah Agung Nomor 854K/Pid/1983, untuk menyimpulkan keduanya telah melakukan zina atau persetubuhan. Berbeda halnya dengan peristiwa kedua, dimana fakta kebersamaan keduanya sejak awal sudah dapat dibuktikan berdasarkan keterangan saksi seorang saksi, yaitu A, yang dihubungkan dengan buku tamu Losmen, sehingga meyakinkan 
hakim keduanya berbuat zina. Kendati hanya seorang saksi (unus testis nullus testis) dan buku tamu juga tidak dapat dikategorikan buku surat karena tidak dibuat di bawah sumpah atau dikuatkan sumpah, namun karena hanya yakin betul, maka hakim menggunakan petunjuk untuk membuktikan terjadinya persetubuhan.

Kedua, ketika menggunakan bukti petunjuk, hakim sangat menekankan adanya fakta kebersamaan kedua terdakwa di dalam kamar dalam rantang waktu yang memungkinkan terjadinya zina. Fakta ini merupakan fakta penghubung untuk menarik kesimpulan terjadinya zina, karena fakta inilah yang akan dihubungkan dengan putusan Mahkamah Agung dalam pembuktian unsur zina atau persetubuhan. Dapat dikatakan, bahwa fakta ini merupakan fakta yang paling menentukan agar rangkaian fakta-fakta yang digunakan untuk membentuk bukti petunjuk menjadi utuh dan tidak terputus. Jika fakta ini tidak ada namun hakim tetap menyimpulkan terjadinya zina, maka akan terjadi penarikan kesimpulannya yang melompat (jumping to conclusion). Itu sebabnya dalam kasus posisi yang pertama, hakim terlebih dahulu menggunakan bukti petunjuk untuk membuktikan kebersamaan kedua terdakwa dalam kamar No. 26 baru kemudian membentuk petunjuk baru yang dihubungkan dengan putusan Mahkamah Agung guna menyimpulkan telah terjadinya persetubuhan. Di sini, subjektivitas hakim sangat dominan. Padahal jika saksi petugas hotel yang mengatar Kumbang ke dalam kamar diperiksa sebagaimana diterangkan saksi C, akan memperjelas kebenaran fakta apakah Kumbang dan Bunga benar bersama di hotel atau tidak, sehingga dominasi subjektif yang berlebihan dan tidak wajar itu dapat diminimalisir. Akan tetapi saksi ini tidak pernah diperiksa baik di kepolisian maupun di pengadilan. Ketiga, penggunaan bukti petunjuk selalu dikaitkan dengan ketidakmampuan terdakwa membuktikan sangkalannya, meskipun secara teoritis kewajiban pembuktian berada pada jaksa penuntut. Keempat, dipergunakannya bukti petunjuk untuk melengkapi alat bukti guna memenuhi prinsip minimum pembuktian.

\section{Bukti Petunjuk yang Memiliki Justifikasi Membuktikan Unsur Delik Zina}

Bukti petunjuk ini bagaikan pisau bermata dua, yang mana di satu sisi dapat menghukum orang yang benar-benar bersalah, namun di sisi lain juga berpotensi menghukum orang yang tidak bersalah. Kekuranghati-hatian menggunakan bukti petunjuk ini berakibat pada pertimbangan hukum suatu putusan yang mengambang, sehingga cenderung kepada penerapan hukum yang sewenang- 
wenang karena didominasi penilaian subjektif yang berlebihan. ${ }^{16}$ Itu sebabnya pembentuk undang-undang memperingatkan hakim ketika menggunakan bukti petunjuk harus dilakukan dengan arif lagi bijaksana, setelah terlebih dahulu mengadakan pemeriksaan dengan penuh kecermatan dan kesaksamaan berdasarkan hati nuraninya.

Menurut Yahya Harahap, peringatan ini harus benar-benar diinsyafi oleh hakim ketika mempergunakan bukti petunjuk, sebab undang-undang sungguhsungguh menuntut kesadaran tanggung jawab hati nurani hakim. Tuntutan tangung jawab hati nurani ini sebagai peringatan agar hakim bersikap arif lagi bijaksana, tidak sembrono dan sewenang-wenang serta harus terlebih dahulu mengadakan pemeriksaan yang menyeluruh secara cermat dan saksama. Artinya penggunaannya sedapat mungkin dihindari kecuali setelah diusahakan mencari dan mempergunakan alat-alat bukti lain sampai batas maksimal namun belum mencukupi barulah dipergunakan. ${ }^{17}$

Menurut Hiariej, jika mengacu pada batasan bukti petunjuk sebagaimana dapat dilihat dalam rumusan Pasal 188 ayat (1), maka syarat-syarat pembentukan bukti petunjuk ialah sebagai berikut: a) harus mempunyai persesuaian satu sama lain atas perbuatan yang terjadi; b) keadaan-keadaan tersebut harus berhubungan satu sama lain dengan kejahatan yang terjadi; c) dilakukan berdasarkan pengamatan hakim yang diperoleh dari keterangan saksi, surat dan keterangan terdakwa. ${ }^{18}$

Lebih rinci lagi, Adami Chazawi menyusun unsur-unsur atau syarat-syarat alat bukti petunjuk ialah: Pertama, adanya perbuatan, kejadian atau keadaan yang bersesuaian. Kedua, ada 2 (dua) macam persesuaian, yaitu bersesuaian antara masing-masing perbuatan, kejadian dan keadaan satu dengan yang lain; maupun bersesuaian antara perbuatan, kejadian dan atau keadaan dengan tindak pidana yang didakwakan. Ketiga, dengan adanya persesuaian yang demikian itu menandakan (menjadi suatu tanda) atau menunjukan adanya 2 hal, yaitu menunjukan bahwa benar telah terjadi suatu tindak pidana, dan menunjukan siapa pembuatnya. Keempat, alat bukti petunjuk hanya dapat dibentuk melalui 3 alat bukti, yaitu keterangan saksi, surat dan keterangan terdakwa.19

Didasari bahwa sangatlah sulit menentukan bukti petunjuk yang memiliki justifikasi membuktikan unsur delik zina. Mengingat, pembentukan dan penilaiannya didasarkan pada nalar subjektivitas hakim. Kendati demikian, jika merujuk pada ketentuan Pasal 188 KUHAP, sumber-sumber hukum dan doktrindoktrin hukum yang berkembang dalam ilmu hukum pidana, maka dapat

\footnotetext{
${ }^{16}$ Yahya Harahap, Op. Cit., hlm. 312.

${ }^{17}$ Ibid.

${ }^{18}$ Eddy O.S. Hiariej, Op. Cit., hlm. 109-110.

${ }^{19}$ Adami Chazawi, Op. Cit., hlm. 68.
} 
disimpulkan bahwa agar bukti petunjuk memiliki justifkasi membuktikan unsur delik zina setidaknya haruslah memenuhi syarat formil dan materil. Syarat formil berisi langkah-langkah atau prosedur yang harus ditempuh sebelum dipergunakan sebagai alat bukti, sedangkan aspek materil berisi unsur-unsur menyangkut subtansi pembentukan bukti petunjuk.

1. Aspek Formil yang harus dipenuhi ialah sebagai berikut:

a. Terlebih dahulu sudah ada alat bukti lain yang digunakan untuk membuktikan delik zina. Hal ini berkaitan dengan keberadaan bukti petunjuk yang tidak dapat berdiri sendiri sehingga sebelum dipergunakan tentunya terlebih dahulu sudah ada alat bukti lain. Mengenai alat-alat bukti ini perlu diperhatikan 4 (empat) hal terkait konsep pembuktian itu sendiri. ${ }^{20}$ Pertama, alat bukti harus relevan. Artinya bukti tersebut berkaitan dengan fakta-fakta yang menunjuk pada suatu kebenaran suatu peristiwa. Kedua, bukti tersebut harus dapat diterima atau admissible. Umumnya suatu bukti yang dapat diterima dengan sendirinya relevan tetapi bukti yang relevan belum tentu dapat diterima, Misalnya keterangan saksi terstimonium de auditu, meski dipandang relevan tapi tidak dapat diterima. Ketiga, tidak diperoleh dengan cara melawan hukum. Misalnya memaksa terdakwa untuk mengakui kesalahannya atau memaksa saksi dengan memberikan menerangkan hal-hal yang tidak dilihat, didengar dan dialaminya. Keempat, setiap bukti yang relevan dan dapat diterima harus dapat dievaluasi oleh hakim. Hakim akan menilai setiap alat bukti tersebut baik kesesuaian antara satu dengan yang lain maupun dengan tindak pidana yang hendak dibuktikan.

b. Alat-alat bukti yang ada belum memenuhi batas minimum pembuktian untuk membuktikan kesalahan terdakwa. Hal ini berkaitan dengan keberadaan bukti petunjuk yang tidak dapat berdiri sendiri dan bersifat sebagai alat bukti pelengkap, yang diperoleh dari keterangan saksi, surat dan keterangan terdakwa. Oleh karena itu, sebelum dipergunakan tentunya sudah ada terlebih dahulu alat bukti lain namun belum memenuhi prinsip minimum pembuktian, sehingga dibutuhkan bukti petunjuk untuk melengkapinya. Sebagai contoh, telah ada keterangan 2 (dua) orang saksi dan bukti surat atau salah satu dari dua bukti tersebut tetapi bukti-bukti itu hanya menerangkan dan membuktikan fakta-fakta yang berdiri sendirisendiri, seperti fakta adanya pemesanan kamar hotel oleh kedua pelaku, kebersamaan pelaku dalam kamar, serta lamanya waktu di dalam kamar,

${ }^{20}$ Eddy O.S. Hiariej, Op. Cit., hlm. 10-12. 
sementara fakta yang hendak dibuktikan adalah masuknya anggota kemaluan laki-laki ke dalam lubang kemaluan perempuan, sehingga untuk membuktikan serta melengkapi alat bukti yang lain guna terpenuhinya asas minimum pembuktian diperlukan bukti petunjuk.

c. Dibentuk melalui tiga alat bukti, yaitu keterangan saksi, surat dan keterangan terdakwa. Tidak boleh membentuk bukti petunjuk di luar dari ketiga alat bukti tersebut. Misalnya membentuk bukti petunjuk melalui keterangan ahli. Hal ini tidak diperkenankan, meskipun dalam keadaan dan kasus tertentu, keterangan ahli sangat membantu untuk memperoleh petunjuk, sebagaimana sering terjadi dalam perkara pembunuhan. Akan tetapi jika melihat rumusan ketentuan Pasal 188 ayat (2) KUHAP, secara tegas telah melarang membentuk bukti petunjuk di luar dari tiga alat bukti tersebut, yang ditegaskan dengan adanya kata "hanya" dalam rumusan tersebut. ${ }^{21} \mathrm{Hal}$ ini berkaitan dengan sifat keterangan ahli yang cenderung didasarkan pada subjektivitas seorang ahli, sekalipun dalam memberikan keterangan harus disampaikan secara objektif. ${ }^{22}$

d. Bukti petunjuk harus diperoleh atau dibentuk oleh hakim melalui sekurangkurangnya dua alat bukti yang disebutkan Pasal 188 ayat (2) KUHAP, baik dalam jenis yang sama maupun dalam jenis yang berbeda. Meskipun batas minimum pembuktian sebagaimana diatur dalam Pasal 183 KUHAP ditujukan bagi hakim untuk membentuk keyakinannya dalam menjatuhkan pidana namun sudah selayaknya sekurang-kurangnya dua alat bukti itu ditarsirkan pula berlaku dalam membentuk alat bukti petunjuk. ${ }^{23}$ Pemberlakuan syarat minimum dua alat bukti dalam membentuk pentunjuk akan memberikan objektivitas dalam penggunaannya sehingga akan memiliki justifikasi yang kuat ketika digunakan. Pemberlakuan ini di sisi lain juga mengharuskan penegakan hukum, khususnya penyidik dan jaksa penuntut umum untuk bersungguh-sungguh sampai batas maksimal dalam mengusahakan dan memperoleh alat bukti lain agar dapat membentuk bukti petunjuk.

2. Aspek Materil

a. Adanya perbuatan kejadian atau keadaan yang bersesuaian. Apa yang dimaksud dengan perbuatan, kejadian atau keadaan adalah fakta-fakta yang menunjukkan tentang telah terjadinya tindak pidana, menunjukkan terdakwa yang melakukan, dan menunjukkan terdakwa bersalah karena melakukan tindak pidana tersebut. ${ }^{24}$ Tentu saja fakta-fakta ini harus dapat dibuktikan

${ }^{21}$ Yahya Harahap, Op. Cit., hlm. 315.

${ }^{22}$ Eddy O.S. Hiariej, Op. Cit., hlm 111-112.

${ }^{23}$ Adami Chazawi, Op. Cit., hlm. 79.

${ }^{24}$ Ibid., hlm. 69 
berdasarkan alat bukti yang sah. Setidaknya terdapat 2 (dua) hal mengenai keberadaan fakta-fakta dalam kaitannya dengan penggunaan bukti petunjuk yang memiliki justifikasi. Pertama, adanya perbuatan kejadian atau keadaan yang bersesuaian itu terdiri dari beberapa fakta. Tidak cukup hanya dengan satu fakta saja. Kedua, beberapa fakta itu harus memiliki hubungan atau korelasi yang jelas dan logis dengan tindak pidana yang hendak dibuktikan. Sebagai contoh, dalam perkara zina maka fakta-fakta itu misalnya adanya hubungan asmara diantara pelaku, fakta kebersamaan pelaku di dalam kamar, lamanya waktu keberadaan di dalam kamar, terdapat cairan sperma pada tubuh atau benda lain di dalam kamar. Khusus peristiwa tertangkap tangan, maka sudah sepatutnya dilakukan visum et repertum terhadap anggota tubuh perempuan agar lebih menjamin penggunaan bukti petunjuk, sebagaimana praktik yang terjadi dalam pembahasan kasus ketiga.

b. Ada 2 persesuaian. Pertama, persesuaian antara masing-masing perbuatan, masing-masing kejadian, masing-masing keadaan atau terhadap yang satu dengan yang lain. Artinya fakta-fakta tentang perbuatan, kejadian dan keadaan yang didapat dari dua atau lebih alat bukti keterangan saksi, keterangan terdakwa, dan atau surat. Meskipun berbeda-beda namun masing-masing ada hubungan yang erat (dapat dirangkai), atau dapat dihubungkan. Hubungannya itu bersifat saling melengkapi, saling menunjang antara satu terhadap yang lainya. Sehingga dapat ditarik suatu kesimpulan (petunjuk) bahwa benar telah terjadi tindak pidana dan terdakwa bersalah melakukannya. Kedua, persesuaian antara perbuatan, kejadian atau keadaan dengan tindak pidana yang didakwakan. Setiap tindak pidana mengandung unsur-unsur. Kompleksitas unsur-unsur itulah yang dinamakan tindak pidana. Oleh karena itu persesuaian dengan tindak pidana tersebut adalah bersesuaian dengan unsur-unsur yang ada, meskipun mungkin isi dari suatu alat bukti yang bersesuaian dengan sebagian unsur saja. Namun, dari persesuaian alat bukti ini dan isi dari alat bukti lainnya harus dapat menunjukkan (dapat disimpulkan) secara akal telah terjadi suatu tindak pidana dan siapa pembuatnya. Dua persesuaian tersebut sifatnya kumulatif dan imperatif. Artinya tidak cukup satu persesuaiannya saja, namun harus kedua-duanya persesuaian. ${ }^{25}$

c. Adanya persesuaian yang yang menandakan adanya kejadian atau keadaan bahwa benar telah terjadi tindak pidana dan siapa pelakunya. Syarat ini

${ }^{25}$ Ibid., hlm. 71-72. 
merupakan kesimpulan dari bekerjanya alat bukti petunjuk sekaligus tujuan dari alat bukti petunjuk. Menurut Adami Chazawi, persesuaian yang menandakan atau menunjukkan dua hal, pertama, menunjukkan bahwa benar telah terjadi tindak pidana; dan kedua, menunjukkan siapa pelakunya haruslah berdasarkan akal yang dapat diterima oleh orang pada umumnya. Akal ini tidak perlu diukur dari seorang genius atau pintar seperti ahli hukum atau sarjana dengan gelar apapun, tetapi cukup dari akal orang pada umumnya. Artinya setiap orang normal dapat menangkap, mengerti dan menerima tentang kebenaran atas dua kesimpulan yang ditarik hakim dari dua persesuaian isi dari dua atau lebih alat bukti dalam hal pembentukan alat bukti petunjuk yang dilakukan hakim. ${ }^{26}$ Oleh karena itu, fakta-fakta yang bersesuaian dalam hubungan yang jelas dan logis menjadi penting agar dalam penarikan kesimpulan dapat diterima akal orang pada umumnya.

\section{Penutup}

Berdasarkan hasil penelitian dan pembahasan yang telah diuraikan sebelumnya maka dapat disimpulkan sebagai berikut:

1. Penggunaan bukti petunjuk sangat didominasi subjektivitas hakim. Bukti ini digunakan setelah hakim yakin betul bahwa terdakwa telah melakukan zina berdasarkan persesuaian dan hubungan logis antara masing-masing fakta dengan unsur zina yang hendak dibuktikan. Ketika menggunakan bukti petunjuk, hakim sangat menekan adanya fakta kebersamaan kedua terdakwa dalam waktu dan tempat yang memungkinkan terjadinya zina. Fakta ini akan dihubungkan dengan Putusan Mahkamah Agung Nomor 854.K/Pid/1983, sehingga ketika terdapat fakta kebersamaan kedua terdakwa di dalam kamar, yang didukung pula dengan fakta-fakta lain yang berkontribusi positif dengan terjadinya zina maka hakim berkesimpulan keduanya telah berbuat zina. Dominasi subjektivitas dan ketidaktepatan penggunaan bukti petunjuk tampak manakala fakta ini tidak ada namun hakim yakin betul bahwa terdakwa telah melakukan zina, maka hakim menggunakan bukti petunjuk untuk membuktikan fakta kebersamaan keduanya, setelah itu barulah kemudian menggunakan bukti petunjuk lagi untuk menyimpulkan terjadinya zina. Selain itu, penggunaanya juga selalu dihubungkan dengan ketidakmampuan terdakwa membuktikan sangkalannya.

2. Bukti petunjuk yang memiliki justifikasi sebagai dasar membuktikan unsur zina atau persetubuhan harus memenuhi 2 aspek, yakni aspek formil dan materil. Aspek formil berkaitan dengan langkah-langkah atau prosedur yang harus 
ditempuh terlebih dahulu sebelum membentuk dan menggunakan alat bukti petunjuk, yakni: Pertama, telah ada alat bukti lain yang digunakan untuk membuktikan delik zina namun belum memenuhi batas minimum pembuktian untuk membuktikan kesalahan terdakwa; Kedua, alat bukti petunjuk harus dibentuk melalui tiga alat bukti, yaitu keterangan saksi, surat dan keterangan terdakwa; Ketiga, harus diperoleh atau dibentuk oleh hakim melalui sekurangkurangnya dua alat bukti, baik dalam jenis yang sama maupun dalam jenis yang berbeda. Sementara itu, aspek materil yang harus terpenuhi ialah: Pertama, adanya fakta materil berupa perbuatan kejadian atau keadaan yang bersesuaian. Faktafakta ini harus dapat menunjukkan tentang telah terjadinya tindak pidana, menunjukkan terdakwa yang melakukan, dan menunjukkan terdakwa bersalah karena melakukan tindak pidana tersebut. Ada 4 hal yang harus diperhatikan berkaiatan dengan fakta-fakta tersebut; (1) fakta-fakta ini harus dapat dibuktikan berdasarkan alat bukti yang sah; (2) adanya perbuatan kejadian atau keadaan yang bersesuaian itu terdiri dari beberapa fakta. Tidak cukup hanya dengan satu fakta saja; (3) beberapa fakta itu harus memiliki hubungan atau korelasi yang jelas dan logis dengan tindak pidana yang hendak dibuktikan; (4) terdapat fakta yang menentukan, yaitu kebersamaan pelaku di dalam kamar atau ruang tertutup atau dalam tempat dan waktu yang memungkinkan dilakukannya zina. Kedua, harus ada 2 persesuaian, yaitu persesuaian antara masing-masing perbuatan, masingmasing kejadian, masing-masing keadaan atau terhadap yang satu dengan yang lain; dan persesuaian antara perbuatan, kejadian atau keadaan dengan tindak pidana yang didakwakan. Ketiga, persesuaian yang menunjukkan bahwa benar telah terjadi tindak pidana dan menunjukkan siapa pembuatnya. Kedua persesuaian itu harus dapat diterima oleh akal orang pada umumnya, tidak perlu diukur dari akal seorang genius tetapi cukup dari akal orang pada umumnya. Artinya setiap orang normal dapat menangkap, mengerti dan menerima tentang kebenaran atas dua kesimpulan yang ditarik hakim dari dua persesuaian isi dari dua atau lebih alat bukti dalam hal pembentukan alat bukti petunjuk yang dilakukan hakim.

\section{Daftar Pustaka}

\section{Buku}

Alfitra. Hukum Pembuktian dalam Beracara Pidana, Perdata dan Korupsi di Indonesia, Raih Asa Sukses, Jakarta, 2017.

Chazawi, Adami. Hukum Pembuktian Tindak Pidana Korupsi, Media Nusa Creative, Malang, 2018. 
Fuady, Munir. Teori Hukum Pembuktian Pidana dan Perdata, Citra Aditya Bakti, Bandung, 2020.

Hamzah, Andi. Hukum Acara Pidana, Sinar Grafika, Jakarta, 2013. Delik-Delik Tertentu (Speciale Delicten) Di Dalam KUHP, Sinar Grafika, Jakarta, 2017.

Harahap, Yahya. Pembahasan Permasalahan dan Penerapan KUHAP: Pemeriksaan Sidang Pengadilan, Banding, Kasasi dan Peninjauan Kembali, Sinar Grafika, Jakarta, 2015.

Hiariej, Eddy O.S. Teori dan Hukum Pembuktian, Erlangga, Jakarta, 2012.

Lamintang, P.A.F. Pembahasan KUHAP Menurut Ilmu Pengetahuan Hukum Pidana dan Yurisprudensi, Sinar Grafika, Jakarta, 2010.

Marzuki, Peter Mahmud. Penelitian Hukum, Prenada Media, Jakarta, 2011.

Soerodibroto, R. Soenarto. KUHP DAN KUHAP Dilengkapi Yurisprudensi Mahkamah Agung dan Hoge Raad, RajaGrafindo Persada, Jakarta, 2006.

Soesilo, R. Kitab Undang-Undang Hukum Pidana (KUHP) Serta KomentarKomentarnya Lengkap Pasal Demi Pasal, Politeia, Bogor, 1995.

Sugandhi R. Kitab Undang-Undang Hukum Pidana dan Penjelasannya, Usaha Nasional, Surabaya, 1981.

\section{Peraturan Perundang-Undangan}

Undang-Undang Nomor 8 Tahun 1981 Tentang Hukum Acara Pidana, Lembaran Negara Republik Indonesia Nomor 76 Tahun 1981, Tambahan Lembaran Negara Nomor 3209. 